\title{
Qualitative research in health: a reflective approach
}

\section{Ellen Synthia Fernandes de Oliveira' \\ ORCID: 0000-0002-0683-2620 \\ Cristina Lavareda Baixinho" \\ ORCID: 0000-0001-7417-1732 \\ Maria Helena Carvalho Valente Presado" \\ ORCID: 0000-0002-6852-7875}

'Universidade Federal de Goiás, Brazil.

"Escola Superior de Enfermagem de Lisboa, Portugal.

How to cite this article:

Oliveira ESF, Baixinho CL, Presado MHCV.

Qualitative research in health: a reflexive approach. Rev Bras Enferm. 2019;72(4):830-1. doi: http://dx.doi.org/10.1590/0034-7167.2019-720401
Qualitative research makes possible the development of health knowledge, because it works with complex phenomena whose totality, besides depth, depends on the intensity. For Minayo, the objective of the qualitative research is to make explicit data, indicators, verified trends and/or construct theoretical models applicable to practice. Therefore, its purpose is to study history, representations, relationships, beliefs, perceptions and opinions, representing the result of the interpretations that subjects construct about the production and reproduction of their lives ${ }^{(1)}$.

Qualitative and quantitative research is diverse in nature, but complements. One treats of the magnitude of the phenomena, and the other of its intensity. One seeks what is repeated, being treated in its homogeneity, and the other, singularities and meaning ${ }^{(2)}$. In a reflexive approach, Taquette insists that qualitative research in health develops, but still shy of its potential. At the international level, qualitative research stands out as a producer of knowledge that subsidizes the clinical practice of nurses ${ }^{(3)}$. It is appropriate for the understanding of phenomena within their intervention context, establishing connections between concepts, representations, beliefs and behaviors, respecting intersubjectivity. It is also observed how contradictory is the low productivity of studies using the qualitative approach as a method.

There is a challenge to develop qualitative research capable of placing this type of research at a level suitable to converge in parallel with quantitative research. Although they are hegemonic in health, it establishes for us, researchers, and expressively translates the potential of qualitative research to the possibilities of greater access to edicts to foster research and to an increase in publication in journals.

Furthermore, this edition brings together articles from the Ibero-American Congress on Qualitative Research (CIAIQ - Congresso Ibero-Americano em Pesquisa Qualitativa) held in Fortaleza State, Brazil, in 2018, in search of greater visibility to qualitative research in health. It also presents studies that address the researchers' perception about the development of health research, from a qualitative perspective, using different approaches and techniques of approach and analysis, in different practice settings. Thus, they reveal the object, objectives, method's theoretical frameworks and approach forms with the object in the qualitative perspective.

A recent book addresses data analysis in qualitative health research. It points out that data analysis techniques advocate that doing science is working simultaneously with theory, method and techniques, in a perspective where this tripod is mutually conditional. Also, they warn that the way of doing depends on what the object demands and the response to the object depends on the assertiveness of questions, instruments, and strategies used in collecting the data/findings ${ }^{(4)}$.

This statement underlies that qualitative research is an inter and transdisciplinary field that crosses humanities, social sciences, and natural sciences. It believes that dialogue between theory and praxis, science - methods and techniques, and multidimensional human development, requires different disciplinary looks, because the understanding of complex realities is hardly grasped from a single prism. This reflection is raised about the place and the space of the qualitative investigation in the nursing clinic. 
Qualitative research dissemination permeated and still permeates health scientific publications. Possibly, by the definition of "Being a Nurse" or the meaning of nursing and knowledge standards necessary for a clinical practice of quality and safety, it is worth reflecting on the 'nursing science'. This must also be done with research methods that develop it and support the clinical decision-making of professionals who empower citizens to autonomy and responsibility for the transitions that they experience and are sensitive to the nursing intervention. This intervention is complex and is always in interaction with a multiplicity of factors that are difficult to measure and replicate. Human experience in health-disease processes, as well as needs, difficulties and expectations are individual, always expressing in the first person.

\section{REFERENCES}

1. Minayo MCS. Sampling and saturation in qualitative research: consensuses and controversies. Rev Pesqui Qualit [Internet]. 2017 [cited 2019 Apr 02];5(7):1-12. Available from: https://edisciplinas.usp.br/mod/resource/view.php?id=2204111

2. Minayo MCS. O desafio do conhecimento: pesquisa qualitativa em saúde. 11. ed. São Paulo: Hucitec, 2008.

3. Minayo MCS, Costa AP. Técnicas que fazem uso da palavra, do olhar e da empatia. Pesquisa qualitativa em ação. Portugal: Ludomedia, 2019.

4. Taquette SR. Análise de dados de pesquisa qualitativa em saúde. In: Congresso Ibero Americano de Investigação Qualitativa, 5, 2016, Porto. Porto: CIAIQ, 2016. p. 1111-20. 